九州大学学術情報リポジトリ

Kyushu University Institutional Repository

\title{
Seed Abortion in Crosses between Diploid and Tetraploid Grapes (Vitis vinifera and V. complex) and Recovery of Triploid Plants through Embryo Culture
}

\section{Wakana, Akira}

Laboratory of Horticultural Science, Division of Agricultural Botany, Department of Plant Resources, Faculty of Agriculture, Kyushu University

Hiramatsu, Michikazu

Laboratory of Horticultural Science, Division of Agricultural Botany, Department of Plant Resources, Faculty of Agriculture, Kyushu University

Park, Sung Min Laboratory of Horticultural Science, Division of Applied Plant Sciences, College of Agriculture and Life Scciences, Kangwon Nation University

Hanada, Nobuaki

Laboratory of Fruit Tree Science, University Farm, Faculty of Agriculture, Kyushu University 他

https://doi.org/10.5109/4524

出版情報: 九州大学大学院農学研究院紀要. 48 (1/2)，pp. 39-50，2003-10-01. Faculty of Agriculture, Kyushu University

バージョン :

権利関係 : 


\title{
Seed Abortion in Crosses between Diploid and Tetraploid Grapes (Vitis vinifera and $V$. complex) and Recovery of Triploid Plants through Embryo Culture
}

\author{
Akira WAKANA ${ }^{1,2 \dagger}$, Michikazu HIRAMATSU ${ }^{1}$, Sung Min PARK ${ }^{3}$, \\ Nobuaki HANADA ${ }^{4}$, Isao FUKUDOME ${ }^{4}$ \\ and Koichi YASUKOCHI ${ }^{4}$ \\ ${ }^{1}$ Laboratory of Horticultural Science, Division of Agricultural Botany, Department of \\ Plant Resources, Faculty of Agriculture, Kyushu University, \\ Fukuoka 812-8581, Japan. \\ (Received June 30, 2003 and accepted July 15, 2003)
}

\begin{abstract}
Interploid crosses between two diploid and two tetraploid grape cultivars were carried out to produce abortive seeds with underdeveloped triploid embryos. Growth regulators influencing the recovery of triploid plants from the underdeveloped embryos were individually examined in vitro using MS medium. Of six growth regulators added to the medium, malt extract (25-1600 mg/1), casein hydrolysate $(20-1500 \mathrm{mg} / \mathrm{l})$, BA $(0.01-1.25 \mathrm{mg} / \mathrm{l})$ and $\mathrm{GA}_{3}(0.1-1 \mathrm{mg} / \mathrm{l})$ did not show obvious effect on the recovery, whereas IAA and NAA showed small promotive effect at the concentration of 0.25 and $1.25 \mathrm{mg} / \mathrm{l}$, and $0.01 \mathrm{mg} / \mathrm{l}$ respectively. Secondly, 23 interploid crosses with four diploid and four tetraploid grape cultivars were carried out reciprocally to produce triploid plants through embryo culture using MS medium supplemented with $1 \mathrm{mg} / \mathrm{l}$ $\mathrm{GA}_{3}$ and $100 \mathrm{mg} / \mathrm{l}$ casein hydrolysate. In the $2 \mathrm{x} \times 4 \mathrm{x}$ crosses, 50 triploid seedlings were successfully recovered from $7.3 \%$ of underdeveloped embryos cultured, while 33 seedlings were recovered from $2.8 \%$ of those in the reciprocals. Of a total of 88 seedlings recovered, 38 were obtained through secondary embryo formation in vitro. From these results, it was suggested that the production rates of triploid plants from the interploid crosses increase with the aid of embryo culture, and that in this case in vitro formation of secondary embryos is an important key factor to increase the rates.
\end{abstract}

\section{INTRODUCTION}

Seedlessness in grape is one of the desirable characters for breeding table grape and raisin grape cultivars. In addition to the breeding with stenospermocarpic grape cultivars (Winkler et al., 1962; Einset and Pratt, 1975; Mullins et al., 1992), breeding of hypo- and hypertetraploid using tetraploid cultivars (Park et al., 1999) and, especially, triploid breeding with diploid and tetraploid cultivars (Yamashita et al., 1993, 1995; Wakana et al., 2002) have been suggested to be the hopeful way for establishing new seedless grape cultivars. Some triploid seedless cultivars were bred in Japan, but so far, no triploid cultivars

\footnotetext{
2 Laboratory of Fruit Tree Science, Division of Agricultural Ecology, Department of Plant Resources, Faculty of Agriculture, Kyushu University 811-2307.

3 Laboratory of Horticultural Science, Division of Applied Plant Sciences, College of Agriculture and Life Sciences, Kangwon National University, Kangwondo 200-71, Korea.

4 Laboratory of Fruit Tree Science, University Farm, Faculty of Agriculture, Kyushu University, Fukuoka 811-2307.

+ Corresponding author (E-mail: wakana@agr.kyushu-u.ac.jp).
} 
producing large-sized and/or high quality berries have been established.

In interploid crosses between diploid and tetraploid plants, seed abortion due to the endosperm degeneration during early embryogenesis is a severe barrier for the production of triploid plants (Esen and Soost, 1973; Sanford, 1983). In the previous study of interploid crosses with seven diploid and four tetraploid grape cultivars (Wakana, et al., 2002 ), it was demonstrated that the $2 \mathrm{x} \times 4 \mathrm{x}$ crosses produced 0.42 seeds per flower and $1.9 \%$ of the seeds germinated and that the $4 \mathrm{x} \times 2 \mathrm{x}$ crosses produced 0.51 seeds per flower and $2.7 \%$ of the seeds germinated. Thus, the seed sowing was not an efficient method for breeding triploid grapes.

To heighten the breeding efficiency in the production of triploid seedlings from the interploid crosses, application of the embryo-rescue methods was studied.

\section{MATERIALS AND METHODS}

\section{Plant materials}

For interploid crosses between diploid and tetraploid grapes, four diploid cultivars and four tetraploid cultivars were used. The diploid cultivars were 'Muscat Bailey A', 'Delaware', 'Rizamat' and 'Sekirei', while the tetraploid cultivars were 'Red Pearl', 'Yufu', 'Cannon Hall Muscat' and 'Kyoho'. 'Muscat Bailey A', 'Delaware', 'Red Pearl', 'Yufu' and 'Kyoho' are intercontinental hybrid cultivars (Vitis complex) with Vitis vinifera and North American Vitis species in their pedigrees, while 'Rizamat' and 'Cannon Hall Muscat' are $V$. vinifera cultivars. 'Sekirei' is classified as $V$. vinifera cultivars, although it has 'Koshu' (V. vinifera ?; Ohmi et al., 1993) in the pedigree. Relation between some of these diploid and tetraploid cultivars was described previously (Ohmi et al., 1993; Wakana et al., 2002). All of these cultivars were 10- to 15-year-old trees grown in a greenhouse located at the Sasaguri orchard of University Farm, Kyushu University, Fukuoka.

\section{Interploid cross}

Twenty-three crosses between $2 \mathrm{x}$ and $4 \mathrm{x}$ cultivars were carried out using the four diploid and four tetraploid cultivars. Number of flower buds of a cluster was adjusted before emasculation so that each cluster has about 100 flower buds. The flower buds were emasculated one or two days before anthesis, sprayed with water to prevent self-pollination and bagged. When the pollination was made, pistils with wet stigma and normal morphology were chosen. Hand pollination was carried out at the full bloom stage of the clusters using fresh pollen from just opened flowers of the pollen parents. Immediately after the pollination, the pollinated flower clusters were bagged again to prevent further crosses. The pollinated fruits were collected at the mature stage in each cross.

\section{Embryo culture}

The mature fruits were surface-sterilized with $70 \%$ ethanol and seeds were extracted out of the fruits under aseptic conditions, or seeds extracted from the fruits under room conditions were sterilized in a solution of $1 \%$ sodium hypochlorite $(\mathrm{NaClO})$ supplemented with $0.1 \%$ Tween-20 for ten minutes and rinsed with sterilized distilled water. Embryos were dissected out of the seeds with a forceps and a surgical knife under a stereoscopic microscope. Then, length of the embryos was measured with the microscope equipped 
with a micrometer. After the measurement, embryos developing beyond a globular stage were placed on MS medium (Murashige and Skoog, 1962) supplemented with 1\% agar, $2 \%$ sucrose and growth regulators, but those lacking viability were eliminated.

To determine the effect of growth regulators on embryo growth and development, the following growth regulators were individually added to MS medium: $0.01,0.05,0.25$ and $1.25 \mathrm{mg} / \mathrm{l}$ naphthalene acetic acid (NAA); $0.01,0.05,0.25$ and $1.25 \mathrm{mg} / \mathrm{l}$ benzyl adenine (BA); 0.01, 0.1, 1, $10 \mathrm{~m} / \mathrm{l}$ gibberellin $\left(\mathrm{GA}_{3}\right) ; 25,100,400$ and $1600 \mathrm{mg} / \mathrm{l}$ malt extract (ME); $20,100,500$ and $2500 \mathrm{mg} / \mathrm{l}$ casein hydrolysate $(\mathrm{CH})$. The medium was adjusted to $\mathrm{pH} 5.7$ with $0.1 \mathrm{~N} \mathrm{NaOH}$ and $0.1 \mathrm{~N} \mathrm{HCl}$, gelled with $1 \%$ agar, dispensed in a $100 \mathrm{ml}$ conical flask at a rate of $20 \mathrm{ml}$ per vessel, and autoclaved at $120^{\circ} \mathrm{C}$ for 14 minutes. $\mathrm{GA}_{3}$ and IAA were added to the medium through filtration with a sterilized cellulose acetate just after the medium was autoclaved. One embryo was planted per vessel.

The medium supplemented with $1 \%$ agar, $2 \%$ sucrose, $1 \mathrm{mg} / \mathrm{l} \mathrm{GA} \mathrm{A}_{3}$ and $100 \mathrm{mg} / \mathrm{CH}$ was used for rescuing underdeveloped embryos in 23 crosses including 11 pair of reciprocal crosses between the diploid and tetraploid cultivars. After germination of the embryos, those growing to plantlets were transplanted to a proliferation medium consisting of MS medium supplemented with $1 \%$ sucrose, $1 \%$ agar and $0.01 \mathrm{mg} / \mathrm{l} \mathrm{NAA}$. The medium was dispensed in a $200 \mathrm{ml}$ conical flask at a rate of $40 \mathrm{ml}$ per vessel and autoclaved as mentioned above. When the plantlets were too large to transplant to the conical flask, they were cut into several sections with at least one leaf, and then the sections were planted in the medium to proliferate. The proliferated plantlets growing within the flasks were transplanted to pots filled with mold-soil mixture (1:1) and habituated at spring of the next year or after about six months of culture.

\section{Chromosome observation}

Chromosome observation in root tip cells from the habituated plantlets was carried out during growing season according to the procedure described by Wakana et al. (2002) or Park et al. (1999a).

\section{RESULTS}

\section{Effect of growth regulators on embryo rescue}

Because of the lack of sufficient abortive triploid seeds from same cross and because of the genetic resemblance of embryos, the seeds from reciprocal crosses between 'Muscat Bailey A' and 'Red Pearl' and those between 'Yufu' and 'Delaware' were used to study the effect of growth regulators on the growth, development and germination of underdeveloped $3 \mathrm{x}$ embryos cultured in vitro. The effect of growth regulators was examined in underdeveloped $3 \mathrm{x}$ embryos from 'Muscat Bailey $\mathrm{A}^{\prime} \times$ 'Red Pearl' for $\mathrm{GA}_{3}$, 'Delaware' $\times$ 'Yufu' for IAA, 'Yufu' $\times$ 'Delaware' for NAA (Table 1) and 'Red Pearl' $\times$ 'Muscat Bailey A' for malt extract, casein hydrolysate and BA (Table 2). In these interploid crosses, sizes of the underdeveloped $3 \mathrm{x}$ embryos varied from very small to large and their morphology varied from highly abnormal to almost normal (Fig. 1-3). Thus, the embryos were randomly chosen to culture in each treatment.

None of these growth regulators showed prominent effect on rescuing the underdeveloped $3 x$ embryos in any concentrations examined (Table 1 and 2). Addition of 
Table 1. Effect of growth regulators on in vitro growth of underdeveloped embryos from crosses between $2 \mathrm{x}$ and $4 \mathrm{x}$ grape cultivars.

\begin{tabular}{|c|c|c|c|c|}
\hline $\begin{array}{l}\text { Growth regulator } \\
\text { (Parentage of } \\
\text { embryos) }\end{array}$ & $\begin{array}{c}\text { Concentration } \\
(\mathrm{m} / \mathrm{l})\end{array}$ & $\begin{array}{l}\text { No. of } \\
\text { embryos } \\
\text { cultured }\end{array}$ & $\begin{array}{c}\text { No. of } \\
\text { embryos } \\
\text { germinating (\%) }\end{array}$ & $\begin{array}{c}\text { No. of } \\
\text { plantlets } \\
\text { established (\%) }\end{array}$ \\
\hline $\mathrm{GA}_{3}$ & 0 & 22 & $4 \quad(18)$ & $4 \quad(18)$ \\
\hline (Muscat Bailey A & 0.01 & 22 & $5 \quad(23)$ & $5 \quad(23)$ \\
\hline \multirow[t]{3}{*}{$\times$ Red Pearl $)$} & 0.1 & 22 & $1 \quad(5)$ & 1 (5) \\
\hline & 1 & 22 & $5 \quad(23)$ & $5 \quad(23)$ \\
\hline & 10 & 22 & $0 \quad(0)$ & $0 \quad(0)$ \\
\hline IAA & 0 & 10 & $0 \quad(0)$ & $\begin{array}{ll}0 & (0)\end{array}$ \\
\hline \multirow[t]{4}{*}{ (Delaware $\times$ Yufu) } & 0.01 & 10 & $1(10)$ & $1(10)$ \\
\hline & 0.05 & 10 & $1(10)$ & $\begin{array}{ll}0 & (0)\end{array}$ \\
\hline & 0.25 & 10 & $2(20)$ & $2(20)$ \\
\hline & 1.25 & 10 & $2(20)$ & $2(20)$ \\
\hline NAA & 0 & 19 & $0 \quad(0)$ & $0 \quad(0)$ \\
\hline \multirow[t]{4}{*}{ (Yufu $\times$ Delaware) } & 0.01 & 19 & 2 (11) & 2 (11) \\
\hline & 0.05 & 19 & 2 (11) & $1 \quad(5)$ \\
\hline & 0.25 & 19 & 1 (5) & $1 \quad(5)$ \\
\hline & 1.25 & 19 & $0 \quad(0)$ & $0 \quad(0)$ \\
\hline
\end{tabular}

Table 2. Effect of growth regulators on in vitro growth of underdeveloped embryos from 'Red Pearl' $(4 \mathrm{x}) \times$ 'Muscat Bailey A' (2x).

\begin{tabular}{|c|c|c|c|c|}
\hline Growth regulator & $\begin{array}{c}\text { Concentration } \\
(\mathrm{mg} / \mathrm{l})\end{array}$ & $\begin{array}{l}\text { No. of } \\
\text { embryos } \\
\text { cultured }\end{array}$ & $\begin{array}{c}\text { No. of } \\
\text { embryos } \\
\text { germinating (\%) }\end{array}$ & $\begin{array}{c}\text { No. of } \\
\text { plantlets } \\
\text { established (\%) }\end{array}$ \\
\hline \multirow[t]{5}{*}{ Malt extract } & 0 & 35 & 4 (11) & $2 \quad(6)$ \\
\hline & 25 & 25 & 4 (16) & 3 (12) \\
\hline & 100 & 25 & $2 \quad(8)$ & $2 \quad(8)$ \\
\hline & 400 & 25 & 1 (4) & $\begin{array}{ll}0 & (0)\end{array}$ \\
\hline & 1600 & 25 & 3 (12) & (8) \\
\hline \multirow[t]{4}{*}{ Casein hydrolysate } & 20 & 25 & $3 \quad(12)$ & $2 \quad(8)$ \\
\hline & 100 & 25 & $\begin{array}{ll}3 & (12)\end{array}$ & $\begin{array}{ll}3 & (12)\end{array}$ \\
\hline & 500 & 25 & $2 \quad(8)$ & 1 (4) \\
\hline & 1500 & 25 & 3 (12) & 3 (12) \\
\hline \multirow[t]{4}{*}{$\mathrm{BA}$} & 0.01 & 10 & $1(10)$ & $1 \quad(10)$ \\
\hline & 0.05 & 10 & $1(10)$ & $1 \quad(10)$ \\
\hline & 0.25 & 10 & $1 \quad(10)$ & $1 \quad(10)$ \\
\hline & 1.25 & 10 & $1 \quad(10)$ & $0 \quad(0)$ \\
\hline
\end{tabular}




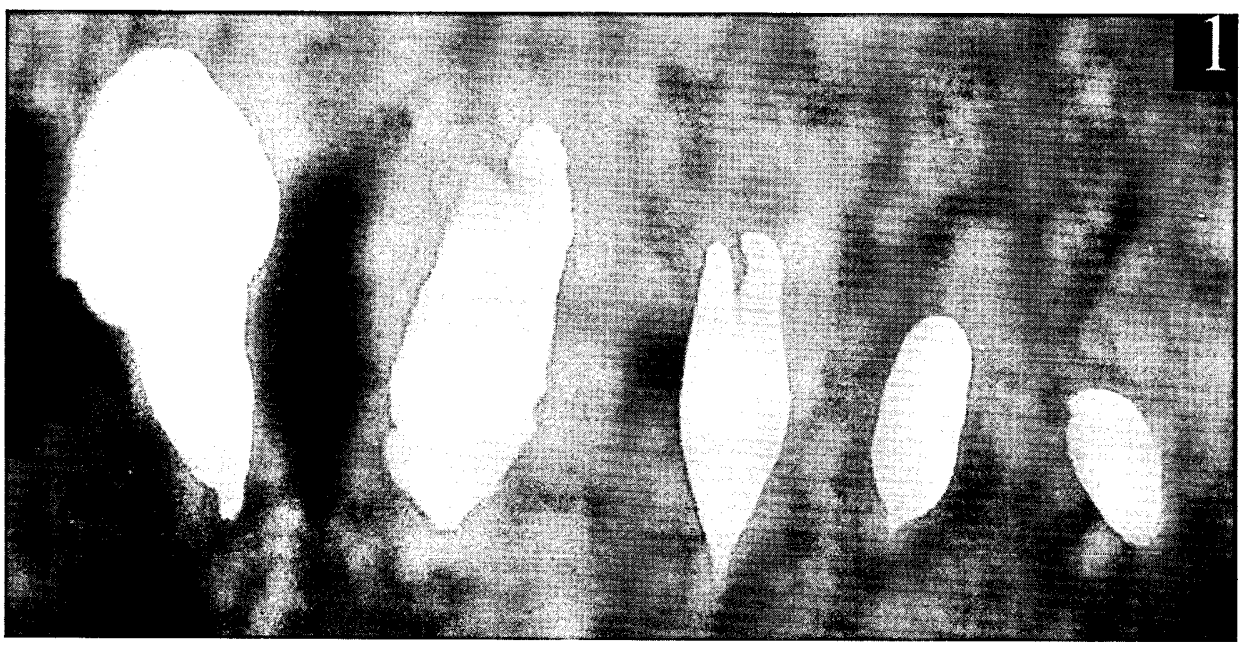

Fig. 1. Morphology of embryos used for embryo culture. The embryos were derived from 'Red Pearl' $\times$ 'Muscat Bailey A' about three months after pollination.
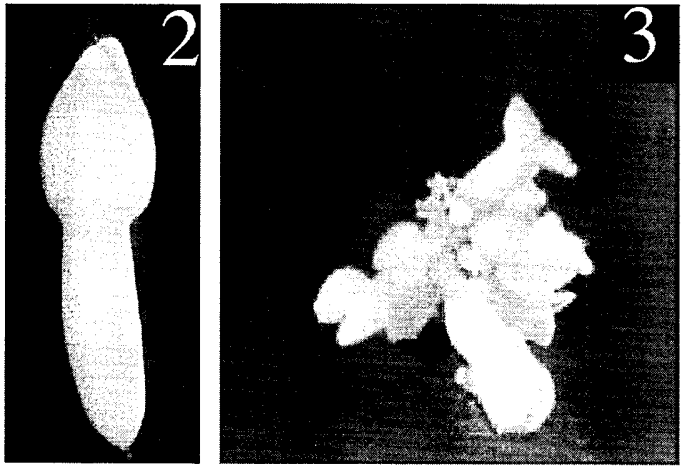

Fig. 2, 3. Embryo morphology in vivo and in vitro.

Fig. 2. An embryo with normal morphology. The embryo was derived from self-pollinated 'Muscat Bailey A' about three months after pollination.

Fig. 3. Multiple embryo formation in a cultured embryo derived from 'Muscat Bailey A' $\times$ 'Red Pearl' about three months after pollination. Note the various sizes of embryos at globular to torpedo stage of embryo development. Note also some embryos show almost normal morphology. 
high concentration of $\mathrm{GA}_{3}(10 \mathrm{mg} / \mathrm{l})$ and NAA $(1.25 \mathrm{mg} / \mathrm{l})$ depressed the growth and development of underdeveloped embryos cultured. IAA and NAA were slightly promoted the growth and development of embryos at the range between 0.01 and $1.25 \mathrm{mg} / \mathrm{l}$ and between 0.01 and $0.25 \mathrm{mg} / \mathrm{l}$ respectively, although the numbers of cultured embryos were small in both media added these regulators. Malt extract and casein hydrolysate slightly promoted the growth of embryos at the concentration of $25 \mathrm{mg} / \mathrm{l}$, and 100 and $1500 \mathrm{mg} / \mathrm{l}$ respectively.

\section{Production of seedlings through embryo culture}

The $2 \mathrm{x} \times 4 \mathrm{x}$ crosses produced 687 seeds of which 326 (47.5\%) seeds contained embryos with various morphology and these embryo sizes varied from very small $(<$ $0.5 \mathrm{~mm}$ ) to large ( $>2 \mathrm{~mm}$ ) (Table 3 ), while the reciprocal crosses produced 1122 seeds of which $834(74.3 \%)$ seeds contained various embryos similar to those observed in the $2 \mathrm{x}$ $\times 4 \mathrm{x}$ crosses (Table 4 ). After about three months culture, a total number of germinated embryos was $62(19.0 \%)$ for the $2 \mathrm{x} \times 4 \mathrm{x}$ crosses and $66(7.4 \%)$ for the $4 \mathrm{x} \times 2 \mathrm{x}$ crosses. Generally, the germination rate of embryos increased with increase of their size when planted on the culture medium (Fig. 4). In the embryos from 'Muscat Bailey A' $\times$ 'Red Pearl' and those from the reciprocal cross, germination rates were more than $50 \%$ when the embryo length was more than $1 \mathrm{~mm}$.

In the $2 \mathrm{x} \times 4 \mathrm{x}$ crosses, rates of plants obtained through embryo culture ranged from 0 to $42.9 \%$ with the average of $7.3 \%$, whereas in the $4 \mathrm{x} \times 2 \mathrm{x}$ crosses the rates ranged from 0 to $5.7 \%$ with the average of $2.9 \%$.

In the $2 \mathrm{x} \times 4 \mathrm{x}$ crosses, when 'Delaware', 'Muscat Bailey A' and 'Sekirei' were used as

Table 3. Results of in vitro culture of underdeveloped embryos from $2 x \times 4 \mathrm{x}$ crosses in grape.

\begin{tabular}{|c|c|c|c|c|c|}
\hline $\begin{array}{r}\mathrm{I} \\
\mathrm{fl} \\
\mathrm{po}\end{array}$ & $\begin{array}{l}\text { No. of } \\
\text { flowers } \\
\text { pollinated }\end{array}$ & $\begin{array}{c}\text { No. of } \\
\text { seeds } \\
\text { obtained }\left(\mathrm{N}^{\mathrm{a}}\right)\end{array}$ & $\begin{array}{l}\text { No. of } \\
\text { embryos } \\
\text { cultured }\end{array}$ & $\begin{array}{c}\text { No. of } \\
\text { embryos } \\
\text { germinating }\end{array}$ & $\begin{array}{c}\text { No. of } \\
\text { plants } \\
\text { acclimated }\left(\%^{\mathrm{b}}\right)\end{array}$ \\
\hline Delaware $\times$ C. H. Muscat & 96 & $54 \quad(38)$ & 32 & 10 & $6(11.1)$ \\
\hline Delaware $\times$ Kyoho & 12 & (4) & 4 & 1 & $1(10.0)$ \\
\hline Delaware $\times$ Yuhu & 885 & $177 \quad(54)$ & 54 & 7 & $6 \quad(3.4)$ \\
\hline Subtotal & 993 & $241 \quad(96)$ & 90 & 18 & $(5.4)$ \\
\hline Muscat B. A×C. H. Muscat & 7 & (5) & 5 & 4 & $3(42.9)$ \\
\hline Muscat B. A X Kyoho & 25 & $51 \quad(33)$ & 32 & 16 & $13(25.5)$ \\
\hline Muscat B. A $\times$ Red Pearl & 433 & $260(126)$ & 119 & 18 & $16 \quad(6.2)$ \\
\hline Subtotal & 465 & 318 (164) & 156 & 38 & $32(10.1)$ \\
\hline Rizamat $\times$ C. H. Muscat & $n e^{c}$ & $51 \quad(28)$ & 25 & 0 & $0 \quad(0)$ \\
\hline Rizamat $\times$ Red Pearl & 45 & $21 \quad$ (11) & 11 & 0 & (0) \\
\hline Rizamat $\times$ Yufu & 105 & $21 \quad(10)$ & 9 & 1 & $(4.8)$ \\
\hline Subtotal & - & $93 \quad$ (49) & 45 & 1 & (1.1) \\
\hline Sekirei $\times$ C. H. Muscat & $n e^{c}$ & (9) & 9 & 1 & (0) \\
\hline Sekirei $\times$ Red Pearl & 167 & (8) & 7 & 4 & $4(20.0)$ \\
\hline Subtotal & - & $37 \quad$ (17) & 16 & 5 & $4 \quad(10.8)$ \\
\hline Total & - & 687 (326) & 307 & 62 & $(7.3)$ \\
\hline
\end{tabular}

${ }^{a}$ No. of seeds with embryo. ${ }^{b}$ No. of acclimated plants / No. of seeds. ${ }^{\mathrm{c}}$ Not examined. 
Table 4. Results of in vitro culture of underdeveloped embryos from $4 \mathrm{x} \times 2 \mathrm{x}$ crosses in grape.

\begin{tabular}{|c|c|c|c|c|c|c|}
\hline $\begin{array}{r}\mathrm{N} \\
\text { flo } \\
\text { poll }\end{array}$ & $\begin{array}{c}\text { No. of } \\
\text { flowers } \\
\text { pollinated }\end{array}$ & $\begin{array}{c}\text { No. of } \\
\text { seeds } \\
\text { obtained }\left(\mathrm{N}^{\mathrm{a}}\right)\end{array}$ & \multirow{2}{*}{$\begin{array}{c}\begin{array}{c}\text { No. of } \\
\text { embryos } \\
\text { cultured }\end{array} \\
5\end{array}$} & \multirow{2}{*}{$\begin{array}{c}\begin{array}{c}\text { No. of } \\
\text { embryos } \\
\text { germinating }\end{array} \\
0\end{array}$} & \multicolumn{2}{|c|}{$\begin{array}{c}\text { No. of } \\
\text { plants } \\
\text { acclimated }\left(\%^{\mathrm{b}}\right)\end{array}$} \\
\hline C. H. Muscat $×$ Delaware & 24 & (6) & & & 0 & $(0)$ \\
\hline C. H. Muscat $\times$ Muscat B. A & 26 & $45 \quad(35)$ & 32 & 1 & 0 & $(0)$ \\
\hline C. H. Muscat ×Rizamat & $n e^{c}$ & (33) & 32 & 1 & 0 & (0) \\
\hline C. H. Muscat $\times$ Sekirei & $n e^{c}$ & $46 \quad$ (33) & 32 & 0 & 0 & $(0)$ \\
\hline Subtotal & - & $142(107)$ & 101 & 2 & 0 & (0) \\
\hline Kyoho $\times$ Delaware & 29 & (3) & 3 & 0 & 0 & $(0)$ \\
\hline Kyoho $\times$ Muscat B. A & 88 & $30 \quad$ (13) & 12 & 0 & 0 & $(0)$ \\
\hline Subtotal & 117 & $40 \quad(26)$ & 15 & 0 & 0 & $(0)$ \\
\hline Red Pearl $\times$ Muscat B. A & 425 & $544(434)$ & 403 & 47 & 25 & $(4.6)$ \\
\hline Red Pearl $\times$ Rizamat & 55 & $53 \quad(45)$ & 43 & 8 & 3 & $(5.7)$ \\
\hline Red Pearl $\times$ Sekirei & 95 & $71 \quad(65)$ & 64 & 1 & 0 & $(0)$ \\
\hline Subtotal & 575 & 668 (544) & 510 & 56 & 28 & $(4.2)$ \\
\hline Yufu $\times$ Delaware & 243 & 158 (111) & 105 & 6 & 4 & $(2.5)$ \\
\hline Yufu $\times$ Rizamat & 84 & 114 (63) & 50 & 0 & 0 & $(0)$ \\
\hline Yufu $\times$ Sekirei $^{d}$ & 60 & $76 \quad(63)$ & 51 & 2 & 1 & (1.3) \\
\hline Subtotal & 387 & 348 (237) & 206 & 8 & 5 & $(1.4)$ \\
\hline Total & - & 1198 (897) & 832 & 66 & 33 & $\left(2.8^{\mathrm{e}}\right)$ \\
\hline
\end{tabular}

${ }^{a}$ No. of seeds with embryo. ${ }^{b}$ No. of acclimated plants/No. of seeds. ${ }^{c}$ Not examined. ${ }^{d}$ Reciprocal cross was not made. 'Average value (\%) includes the data of 'Yufu' $\times$ 'Sekirei'. Average value (\%) without that of 'Yufu' $\times$ 'Sekirei' is 2.9 .

seed parents, seedlings were successfully obtained from 5.4, 10.2 and $10.8 \%$ of seeds through embryo culture respectively. When 'Rizamat' was used as a seed parent, however, only one seedling was derived from 93 seeds through embryo culture. In the $4 x \times 2 x$ crosses, when 'Red Pearl' and 'Yufu' were used as seed parents, underdeveloped embryos from 4.2 and $1.4 \%$ of the seeds developed into seedlings in vitro, respectively. When 'Cannon Hall Muscat' was used as a seed parent, only two of 107 embryos germinated in vitro, but no plants were established. In two cross combinations where 'Kyoho' was used as a seed parent, none of cultured embryos germinated.

\section{Production of seedlings through secondary embryo formation in vitro}

Multiple embryo formation due to secondary embryo formation from initial embryo was observed not only in several triploid seeds but also in many embryos cultured (Fig.2). The secondary embryos often initiated in blimp-shaped embryos without hypocotyls and/or cotyledons (Fig. 3). In the cultured embryos, a total of 101 embryos showed multiple embryo formation in vitro (Table 5). This was $8.9 \%$ of embryos cultured. The rate of embryos showing multiple embryo formation in vitro was higher in the embryos from the $2 \mathrm{x} \times 4 \mathrm{x}$ crosses $(23.5 \%)$ than those from the reciprocals (3.5\%).

Morphology of the additional secondary embryos was different in different embryos. Among these embryos, almost normal ones with well-developed hypocotyls and cotyledons germinated and developed into plants. Thirty-eight embryos forming secondary 


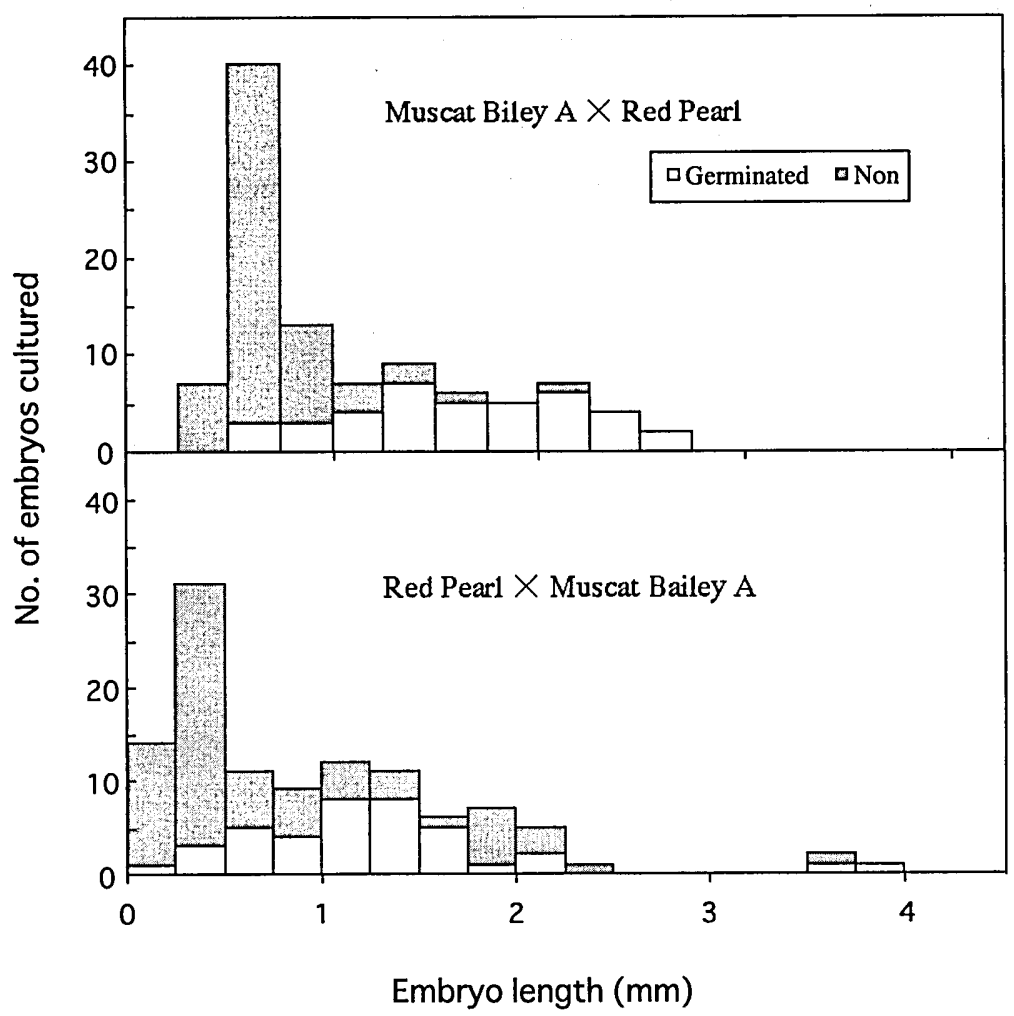

Fig. 4. Frequency distributions of embryos with different length and their germination rates after three months of culture. White bar: germinated; shaded bar: non-germinated.

embryos resulted in successful establishment of plants. This was $45.8 \%$ of embryos resulting in plants. In the $2 \mathrm{x} \times 4 \mathrm{x}$ crosses, $38.9 \%$ of embryos forming secondary embryos resulted in successful establishment of plants, while in the $4 \times \times 2 x$ crosses $34.5 \%$ of embryos forming secondary embryos resulted in successful establishment of plants. In the $2 \mathrm{x} \times 4 \mathrm{x}$ crosses, plants derived through secondary embryo formation were 28 of 50 established plants (46\%), whereas in the $4 \mathrm{x} \times 2 \mathrm{x}$ crosses they were 10 of 33 (30.3\%).

\section{Characteristics of triploid seedlings established}

Chromosome observation in root tip cells of the seedlings established through embryo culture indicated that all were triploid plants with 57 chromosomes, except for one tetraploid plant with 76 chromosomes. The characteristics and origin of the exceptional tetraploid seedlings derived from 'Red Pearl X'Muscat Bailey A' has been reported elsewhere (Park et al., 2002a). After acclimating, the triploid seedlings grew rapidly and showed higher vigor than diploid seedlings derived from self-pollination of their parents. 
Table 5. Rate of plants obtained through secondary embryo formation in cultured $3 \mathrm{x}$ embryos from reciprocal crosses between $2 \mathrm{x}$ and $4 \mathrm{x}$ grape cultivars.

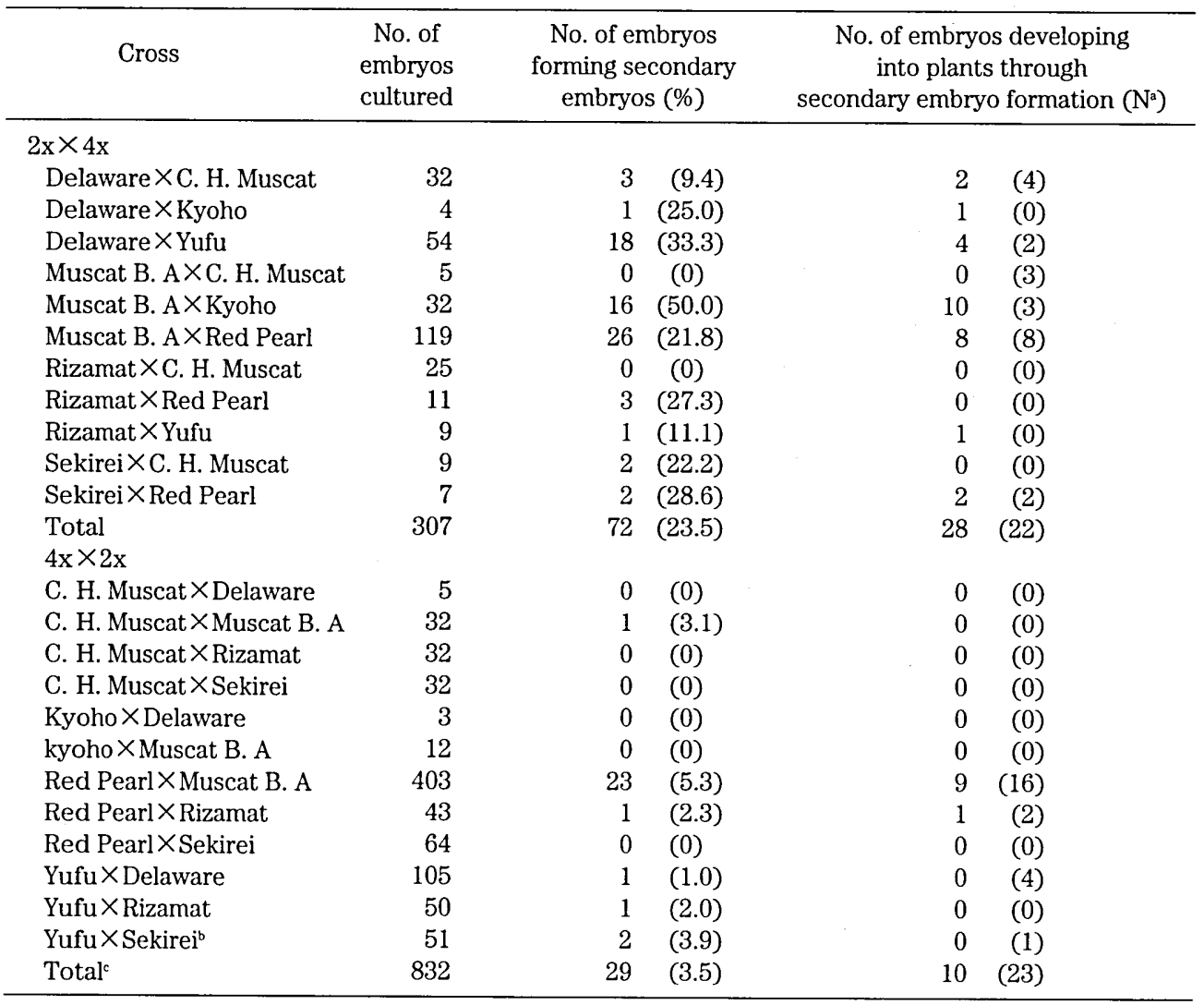

${ }^{a}$ No. of embryos developing into plants without secondary embryo formation in vitro. ${ }^{b}$ Reciprocal cross was not made. 'Values include the data of 'Yufu' X'Sekirei'.

They flowered by two to three years after planting and some set small seedless fruits and the other set no fruits. The characteristics of their $\mathrm{GA}_{3}$-treated and non-treated berries will be published elsewhere.

\section{DISCUSSION}

The present study demonstrated that the efficiency of triploid breeding is heightened by in vitro culture of underdeveloped embryos from interploid crosses between diploid and tetraploid grape cultivars. In the same cross combinations, the rates of established seedlings to pollinated flowers are high in embryo culture as compared with seed sowing reported previously (Wakana et al., 2002). In 'Muscat Bailey A'×'Red Pearl', for example, two seedlings were obtained from 549 flowers through seed sowing, whereas 16 seedlings 
were obtained from 433 flowers through embryo culture, i.e., the rates were $0.4 \%$ for seed sowing and $3.7 \%$ for embryo culture. The similar facts that embryo culture increased the rate of seedling production were also prominent in 'Red Pearl' $\times$ 'Muscat Bailey A' and 'Muscat Bailey A' $\times$ 'Kyoho' where the rates were $0 \%$ and $0.7 \%$ for seed sowing and $5.9 \%$ and $52.0 \%$ for embryo culture respectively.

When reciprocal crosses between $2 \mathrm{x}$ and $4 \mathrm{x}$ cultivars are compared, the results of triploid seedling production are different from those of seed sowing reported previously (Wakana et al., 2002). In the present embryo culture, the rates of established seedlings to pollinated flowers in the $2 \mathrm{x} \times 4 \mathrm{x}$ crosses were higher than those in the $4 \mathrm{x} \times 2 \mathrm{x}$ crosses, whereas in the seed sowing no difference was detected between reciprocal crosses between $2 \mathrm{x}$ and $4 \mathrm{x}$ cultivars. This may be due to the difference of plant material between the experiments, or due to delaying of embryo abortion in the $2 \mathrm{x} \times 4 \mathrm{x}$ crosses.

Yamashita et al. $(1993,1995)$ also reported that the rate of $3 \mathrm{x}$ seedlings established per flower increased by in vitro culture of embryos from crosses between diploid and tetraploid grape cultivars, although they used embryos extracted from immature berries as materials for seedling production. In the present study with underdeveloped embryos from mature berries, none of embryos from several $2 \mathrm{x} \times 4 \mathrm{x}$ cross combinations and two thirds of $4 \mathrm{x} \times 2 \mathrm{x}$ cross combinations developed into seedlings. Furthermore, the six growth regulators added at various concentrations to the MS medium did not exhibit prominent effect on the growth and germination of embryos and subsequent seedling production. These may be related to the presence of several depressive factors such as low viability and very abnormal morphogenesis in the underdeveloped embryos from mature berries.

On the other hand, our result suggests that in vivo and in vitro occurrence of multiple secondary embryos in underdeveloped embryos is important to increase the production of $3 \mathrm{x}$ seedlings, because in vitro morphogenesis in some of the multiple embryos was almost normal and they were develop into seedlings, and because the rate of underdeveloped embryos showing secondary embryo formation was considerably high in most cross combinations.

Esen and Soost (1973) have reported multiple embryo formation in the abortive triploid seeds of monoembryonic diploid citrus cultivars pollinated with tetraploid cultivars. They postulated that the abnormal polyembryo formation occurring only under abortive conditions is related to the malfunction of the endosperm such as hormonal unbalance. In this study of embryo culture, however, effect of six growth regulators on the formation of secondary embryos was not detected. So far, the method and mechanism to induce the initiation of multiple embryos are not clear.

Formation of secondary embryos or somatic embryogenesis in grape embryos has been reported in embryo culture (Yamashita et al., 1993, 1995) and in ovulo embryo culture (Emershad and Ramming, 1984, 1994; Emershad et al., 1989), while polyembryonic seed formation has been reported in the seeds from Vitis vinifera $\times V$. riparia (Bouquet, 1982). Considering these and the present results, it seems that grape zygotic embryos have some extent of potential to initiate somatic embryos irrespective of the presence or absence of growth regulators. The fact that in many grapevine genotypes the connective of anthers is a highly regenerative tissue when cultured in vitro and give rise to somatic embryos with high frequencies (Mullins et al., 1992) may partially support this 
postulation.

The size of embryos excised from mature berries was varied from very small to very large and most of them were underdeveloped and/or very small. Another fact that the germination rate of cultured embryos decreased with decrease of their size (Fig. 4) suggests the necessity of in vitro culture before the embryos fall into abortive situation. Thus, to obtain $3 \mathrm{x}$ seedlings from these crosses with high frequencies, in vitro culture of embryos extracted from immature berries may be necessary before they abort or fall into abortive situation due to endosperm degeneration.

In the crosses with stenospemocarpic cultivars as seed parents, seedlings were derived through in ovulo embryo culture with high frequencies (Ramming and Emershad, 1982: Cain et al., 1983; Emershad and Ramming, 1984; Spiegel-Roy et al., 1985; Goldy et al., 1988; Emershad et al., 1989; Gray et al., 1990). The same embryo-rescue techniques were also applied to aneuploid plant production from triploid grapes (Park et al., 1999a) and triploid plant production from crosses between diploid and tetraploid grapes (Yamashita et al., 1998). Application of embryo-rescue techniques such as these may further improve the efficiencies of triploid breeding in grape.

\section{REFERENCES}

Bouquet, A. 1982 Premieres observations sur le determisme genetique de la polyembryonie spontanee chez un hybride interspecifique Vitis vinifera $\times V$. riparia. Vitis, 21: 33-39

Cain, D. W., R. L. Emershad and R. E. Tarailo 1983 In ovulo embryo culture and seedling development of seeded and seedless grapes (Vitis vinifera L.). Vitis, 22: 9-14

Einset, J. and C. Pratt 1975 Grape. In "Advances in fruit breeding" edited by Janick, J. and J. N. Moore, Purdue Univ. Press, West Lafayette, pp. 130-153

Esen, A. and R. K. Soost 1973 Seed development in Citrus with special reference to $2 \mathrm{x} \times 4 \mathrm{x}$ crosses. Amer. J. Bot., 60: 448-462

Emershad, R. L. and D. W. Ramming 1984 In ovulo embryo culture of Vitis vinifera L. c.v. Thompson Seedless. Amer. J. Bot., 71: 873-877

Emershad, R. L. and D. W. Ramming 1994 Somatic embryogenesis and plant development from immature zygotic embryos of seedless grapes (Vitis vinifera L.). Plant Cell Report, 14: 6-12

Emershad, R. L. , D. W. Ramming and M. D. Serpe 1989 In ovulo embryo development and plant formation from stenospermic genotypes of Vitis vinifera. Amer. J. Bot., 76: 397-402

Goldy, R. R., R. L. Emershad, D. W. Ramming and J. Chaporo 1988 Embryo culture as a means of introgressing seedlessness from Vitis vinifera to Vitis rotundifolia. HortScience, 23: 886-869

Gray, D. J., J. A. Mortensen, C. M. Benton, R. E. Durham and G. A. Moore 1990 Ovule culture to obtain progeny from hybrid seedless bunch grapes. J. Amer. Soc. Hort. Sci., 115: 1019-1024

Mullins, M. G., A. Bouquet and L. E. Williams 1992 Biology of the grapevine. Cambridge Univ. Press, Cambridge

Murashige, T. and F. Skoog 1962 A revised medium for rapid growth and bioassays with tobacco tissue cultures. Physiol. Plant., 15: 473-497

Ohmi, C., A. Wakana and S. Shiraishi 1993 Study of the parentage of grape cultivars by the genetic interpretation of GPI-2 and PGM-2 isozymes. Euphytica, 65: 195-202

Park, S. M., M. Hiramatsu and A. Wakana 1999a Aneuploid plants derived from crosses with triploid grapes through immature seed culture and subsequent embryo culture. Plant Cell, Tissue and Organ Culture, 59: 125-133

Park, S. M., A. Wakana and M. Hiramatsu 1999b Most hypotetraploid seedlings from self-pollinated tetraploid grapes (Vitis complexes) have abnormal cotyledons. J. Fac. Agr., Kyushu Univ., 46: 281-294

Park, S. M., A. Wakana, M. Hiramatsu and K. Ureshino 2002a A tetraploid plant from $2 \mathrm{x} \times 4 \mathrm{x}$ crosses in Vitis and its origin. Euphytica, 126: 345-353

Park, S. M., A. Wakana, J. H. Kim and C. S. Jeong $2002 b$ Male and female fertility in triploid grapes 
(Vitis complex) with special reference to the production of aneuploid plants. Vitis, 41: 11-19

Ramming, D. W. and R. L. Emershad 1982 In ovulo embryo culture of seeded and seedless Vitis vinifera L. HortScience., 17: 487

Sanford, J. G. 1983 Ploidy manipulations. In "Methods in fruit breeding" edited by Moore, J. N. and J. Janick, Purdue Univ. Press, West Lafayette, pp. 100-123

Spiegel-Roy, P., I. Baron and U. Lavi 1985 In vitro culture and plant formation from grape cultivars with abortive ovules and seeds. J. Amer. Soc. Hort. Sci., 110: 109-112.

Wakana, A., M. Hiramatsu, S. M. Park, H. Hanada, I. Fukudome and B. X. Ngo. 2002. Degree of abortion and germination rates in triploid seeds from crosses between diploid and tetraploid grapes (Vitis vinifera L. and V. complex). J. Fac. Agr., Kyushu Univ., 46: 281-294

Winkler, A. J., J. A. Cook, W. M. Kliewer and L. A. Lider 1962 General viticulture. California Univ. Press, Berkley

Yamane, H., A. Kurihara and R. Tanaka 1978 Studies on polyploidy breeding in grapes. I. Chromosome numbers of large-berried grape varieties grown in Japan. Bull. Fruit Tree Res. Stn., E2: 1-8 (in Japanese with English summary)

Yamashita, H., S. Horiuchi and T. Taira 1993 Development of seeds and the growth of triploid seedlings obtained from reciprocal crosses between diploids and tetraploids grapes. J. Japan. Soc. Hort. Sci., 63: 349-255 (in Japanese with English summary)

Yamashita, H., T. Hanuda and H. Shiba 1995 In vitro culture of embryos obtained by crossing tetraploid cultivar Kyoho with diploid cultivars. J. Japan. Soc. Hort. Sci., 65: 719-724 (in Japanese with English summary)

Yamashita, H., I. Shigehara and T. Hanuda 1998 Production of triploid grapes by in ovulo embryo culture. Vitis, 37: 113-117 